\title{
Abscisic Acid Application Timing and Concentration Affect Firmness, Pigmentation, and Color of 'Flame Seedless' Grapes
}

\author{
M. Cecilia Peppi, ${ }^{1}$ Matthew W. Fidelibus, and Nick Dokoozlian ${ }^{2}$ \\ Department of Viticulture and Enology, University of California, \\ One Shields Avenue, Davis, CA 95616
}

Additional index words. anthocyanins, ABA, ethephon, table grapes, fruit quality, softening, Vitis vinifera

\begin{abstract}
Poor coloration of red grapes grown in warm regions is a frequent problem that decreases production efficiency. Most table grape growers use ethephon to improve color, but its influence on color development is erratic, and it may reduce berry firmness. Application of S-abscisic acid (ABA) to grapes can increase the anthocyanins in their skins, but no protocols have been established regarding its potential commercial use. Therefore, we evaluated the effects of $\mathrm{ABA}$ and ethephon treatments on fruit quality characteristics, including those related to firmness and color, on 'Flame Seedless' grapes (Vitis vinifera L.) in several experiments over three consecutive seasons. Abscisic acid had few effects on berry weight or juice composition, but it increased berry softening and skin anthocyanin concentrations. The effect of $\mathrm{ABA}$ on berry firmness was similar to ethephon. With respect to skin anthocyanin concentration and fruit color characteristics, $300 \mathrm{mg} \cdot \mathrm{L}^{-1} \mathrm{ABA}$ applied at veraison was superior to the other $\mathrm{ABA}$ concentrations and to ethephon applied at any of the times tested. Moreover, any concentration of $\mathrm{ABA}$ between 75 and $300 \mathrm{mg} \cdot \mathrm{L}^{-1}$ applied after veraison improved color better than ethephon applied at the same time. There was a highly significant inverse curvilinear relationship between skin anthocyanin concentration and the lightness and hue of the berries. Anthocyanin concentrations between 0.01 and $0.04 \mathrm{mg} \cdot \mathrm{cm}^{-2}$ had little effect on berry lightness and hue, so researchers should consider measuring color, not just anthocyanins, when evaluating the quality of red table grapes.
\end{abstract}

In California, table grapes occupy almost $15 \%$ of the total land area on which grapes are grown. Most table grapes are cultivated in regions with hot climates, especially the Central and Southern San Joaquin Valley (CASS, 2004). Grapes grown in warm climate regions may develop less red color than those from cooler regions (Kliewer, 1970; Winkler et al., 1974) because high temperatures inhibit anthocyanin accumulation in grape berry skins (Spayd et al., 2002). 'Flame Seedless' is by far the most widely planted red-fruited table grape cultivar grown in California with almost 10,000 ha planted (CASS, 2004), although color development of this grape may be inadequate in some regions and in years with particularly high temperatures during ripening.

Received for publication 1 May 2006. Accepted for publication 5 July 2006. This work was funded by Valent BioSciences and the California Table Grape Commission. We thank Kimberly Cathline, Jorge Osorio, Don Katayama, Karin Kawagoe, and Nona Ebisuda for technical assistance and Andrew Walker, Doug Adams, and Jennifer Hashim for their helpful comments on the manuscript.

${ }^{1}$ To whom reprint requests should be addressed; e-mailmcpeppi@ucdavis.edu.

${ }^{2}$ Current address: E. \& J. Gallo Winery, 600 Yosemite Blvd., Modesto, CA 95353.
Poor coloration substantially reduces the economic value of table grapes. Cultural practices such as leaf removal, shoot thinning, and cluster thinning (Dokoozlian and Hirschfelt, 1995) can enhance the quality of 'Flame Seedless' grapes, but often these practices are insufficient to remedy color problems. In fact, treatments such as girdling or application of gibberellic acid $\left(\mathrm{GA}_{3}\right)$, which are necessary to meet minimum standards for berry size, have detrimental effects on color development. To improve berry color, growers generally apply ethephon, an ethylene-releasing compound, but its effects on color are inconsistent (Jensen et al., 1975, 1982; Szyjewicz et al., 1984), and the concentrations commonly needed for color improvement often reduce fruit firmness (Jensen et al., 1982; Szyjewicz et al., 1984).

The role of the plant growth regulator (PGR) abscisic acid (ABA) in seed germination, stomatal closure, and inhibition of shoot growth is well known (Taiz and Zeiger, 2002; Walton, 1980; Zeevaart and Creelman, 1988), but ABA is also associated with the physiology of fruit maturation in grapes, including anthocyanin accumulation in berry skins (Coombe, 1976; Coombe and Hale, 1973; Düring et al., 1978; Kataoka et al., 1982). In fact, the suppressive effect that high temperatures have on anthocyanin accumulation by grapes might be a consequence of reduced $\mathrm{ABA}$ concentrations in their skins (Lee et al., 1979; Tomana et al., 1979). Others showed that exogenous ABA treatment of grapes can increase skin anthocyanin concentrations (Han et al., 1996; Kataoka et al., 1982; Lee and Tomana, 1980; Lee et al., 1997; Matsushima et al., 1989), but the high cost of ABA precluded the development of practical applications for viticulture, and the compound was never tested on 'Flame Seedless'.

The quantity and composition of anthocyanins in the berry skin influences its color (Mazza, 1995; Ribéreau-Gayon, 1982), but few studies have examined the relationship between skin anthocyanin concentration and the perception of grape berry color (Carreño et al., 1997; Kim et al., 1998). In most viticultural studies, the term "color" is used interchangeably with skin anthocyanin concentrations, although the relationships between a fruit's pigment concentrations and its color may be nonlinear (Lancaster et al., 1997). Therefore, direct measurements of color, in terms of lightness, chroma, and hue, might be more informative than the concentration of pigments in the berry's skins (Carreño et al., 1997; Fernández-López et al.,1998; McGuire, 1992). Furthermore, if skin anthocyanin concentration and the color characteristics of table grapes are well correlated, color measurements may serve as a simple, rapid, and nondestructive alternative to skin anthocyanin measurements for evaluating the effects of cultural practices on the pigmentation of grape berries.

Recent methods that have been developed to reduce the cost of producing $\mathrm{ABA}$ may make its use on grapes economically feasible. Thus, several experiments were conducted to determine the effect of ABA applied at different timings and concentrations on 'Flame Seedless' fruit quality attributes, including composition, firmness, and skin anthocyanin concentrations. Another objective was to determine the relationship between color characteristics, in terms of lightness, chroma, and hue, and the concentration of anthocyanins in the skins of 'Flame Seedless' berries.

\section{Materials and Methods}

\section{Grapevines and growing conditions}

Experiments were conducted during three consecutive seasons (2003 through 2005) on own-rooted 'Flame Seedless' grapevines planted in 1988 at the Kearney Agricultural Center, Parlier, Calif. Vines were trained to a bilateral cordon, spur-pruned, and trellised to the traditional California T-system (Winkler et al., 1974). Vines were spaced $2.4 \mathrm{~m}$ within rows and $3.6 \mathrm{~m}$ between rows. Each row was oriented east to west. Standard cultural practices were followed every year; shoots were thinned to one primary shoot per node, gibberellic acid was applied for thinning (15 g per ha at $90 \%$ anthesis) and for berry sizing ( $50 \mathrm{~g}$ per ha at 7 to $8 \mathrm{~mm}$ berry diameter and 5 to $7 \mathrm{~d}$ later), and basal leaves and lateral shoots were removed (Dokoozlian and Hirschfelt, 1995). Ethephon is commonly 
applied at rates of 250 to $280 \mathrm{~g}$ per ha at veraison to improve color (Dokoozlian and Hirschfelt, 1995; Jensen et al., 1982), but it was only applied as a treatment in 2003 and 2005 to assess the relative efficacy of ABA and ethephon. Experimental vines were selected on the basis of uniformity of vegetative growth and crop load after fruit set.

\section{Chemicals}

ABA (S-abscisic acid) was supplied by Valent BioSciences Corporation (Libertyville, Ill).

\section{3 experiment}

Experimental design and treatments. In 2003, a randomized complete-block design was used with vines as blocks and clusters as experimental units. There were 15 replicates of each treatment, which were all harvested on 24 July 2003. The eight treatments were combinations of ABA and ethephon applied with a handheld sprayer until runoff at different times: 1000 or $2000 \mathrm{mg} \cdot \mathrm{L}^{-1} \mathrm{ABA}$ applied at veraison (2 July 2003), 1000 $\mathrm{mg} \cdot \mathrm{L}^{-1} \mathrm{ABA}$ at veraison plus ethephon (250 $\mathrm{mg} \cdot \mathrm{L}^{-1}$ ) at veraison or 1 week after (10 July 2003), ethephon at veraison, ethephon at veraison plus $1000 \mathrm{mg} \cdot \mathrm{L}^{-1} \mathrm{ABA} 1$ week after, ethephon plus $1000 \mathrm{mg} \cdot \mathrm{L}^{-1} \mathrm{ABA}$ applied 1 week after veraison, and an untreated control. For all the experiments and years, veraison was defined as the time when $5 \%$ to $10 \%$ of the berries were soft. Data were subjected to the general linear models procedure (PROC GLM) of SAS statistical software (SAS Institute, Cary, N.C.). When treatment effects were significant $(\alpha=0.05)$, treatment means were separated by Duncan's new multiple range test.

Berry sampling and fruit analyses. Fruits were harvested after soluble solids reached $16.5^{\circ} \mathrm{C}$ Brix and at least one of the treatments had well-colored fruit. At harvest, clusters were weighed and 50 berries per cluster were removed and used for fruit quality analyses. Berries were weighed and then macerated in a blender. Soluble solids of the filtered juices were measured with a temperature-compensating digital refractometer (Palette 101; Atago, Farmingdale, N.Y.). Titratable acidity was determined by titration of a 5-mL aliquot of juice diluted in deionized water $(1: 4, \mathrm{v}: \mathrm{v})$ with $0.133 \mathrm{~N} \mathrm{NaOH}$ to an 8.2 end point using an automatic titrator (900A; Orion Research, Boston) and expressed as grams of tartaric acid per liter of juice. Ten berries from each cluster were used for firmness analysis. A razor blade was used to remove the skin on a small area at one side of the equator exposing the flesh. Mesocarp puncture resistance measurements, indicators of fruit firmness, were made on the exposed flesh using a 4.8 -mm-diameter cylindrical probe affixed to a U.C. fruit firmness tester (Jensen et al., 1975).

Anthocyanin analyses. Ten berries from each cluster were collected, frozen, and kept at $-20{ }^{\circ} \mathrm{C}$ for anthocyanin analysis. Two 10-mm-diameter skin disks were removed from each frozen berry using a cork borer and forceps taking care to remove only the skin without any pulp. The skin disks were rinsed once with tap water, again with deionized water, and blotted dry with paper towels. The disks were then placed in polystyrene tubes with methanol $(1 \mathrm{~g}$ of skin per $10 \mathrm{~mL}$ of methanol) and extracted in darkness at room temperature for 48 hours. Samples were removed from the darkness, manually agitated for 5 seconds, and then a $2-\mathrm{mL}$ aliquot was acidified with $1 \% \mathrm{HCl}$ to adjust the $\mathrm{pH}$ for maximum anthocyanin absorption. The absorbance of each sample was determined at $520 \mathrm{~nm}$ using a spectrophotometer (Milton Roy 601; Spectronic, Rochester, N.Y.). Readings were expressed as milligrams of total anthocyanins as malvidin-3-glucoside per area of skin $\left(\mathrm{cm}^{2}\right)$ (Peppi, 2004).

\section{4 experiment}

In 2004, a factorial treatment structure was used with four ABA concentrations ( 0 , 75,150 , or $300 \mathrm{mg} \cdot \mathrm{L}^{-1}$ ) and three application times (preveraison, 28 May; veraison, 14 June; and postveraison, 28 June). The ABA and application time factors were nested within two harvest dates, 14 and 28 July 2004. The first harvest occurred after soluble solids reached $16.5^{\circ} \mathrm{C}$ Brix and at least one of the treatments had well-colored fruit. The ABA concentrations and application timings tested in 2004 were suggested by the results of the 2003 experiment. Ethephon was not evaluated in 2004 because there were not enough uniform clusters to accommodate additional treatments. Application method was the same as for 2003. Data were subjected to the PROC GLM of SAS statistical software. When effects of factors were significant $(\alpha=0.05)$, they were separated by Duncan's new multiple range test.

Data collection was the same as described for 2003 except that titratable acidity of the filtered juices was not measured on the first harvest date as a result of instrument malfunction, and that $\mathrm{pH}$ of filtered juices was measured with a meter (SA720; Orion Research) on the second harvest date.

\section{5 experiment}

In 2005, a split-split-plot design was used in which harvest date $(11,18$, and 25 July) was the main plot factor, application timing [13 June (preveraison), 21 June (veraison), and 5 July (postveraison)] was the subplot factor, and plant growth regulator treatment $\left(0,75,150\right.$, or $300 \mathrm{mg} \cdot \mathrm{L}^{-1} \mathrm{ABA}$, or 250 $\mathrm{mg} \cdot \mathrm{L}^{-1}$ ethephon) was the subsubplot factor. The first harvest occurred after soluble solids reached $16.5^{\circ} \mathrm{C}$ Brix and at least one of the treatments had well-colored fruit. Treatments were applied with a handheld sprayer until runoff. Data were subjected to the PROC GLM of SAS statistical software. When there were significant $(\alpha=0.05)$ interactions between factors, the effect of one factor was determined at each level of the other factor by separating the means by Duncan's new multiple range test or by LSD as appropriate (Gomez and Gomez, 1984). Anthocyanin data and color characteristics were subjected to regression analyses using SigmaPlot (Systat Software Inc., Richmond, Calif.).

Data collected were similar to the other years except that several additional variables were measured in 2005. These included $\mathrm{pH}$ and titratable acidity of the filtered juices, which were determined at all harvest dates. In addition, the color characteristics-lightness $\left(\mathrm{L}^{*}\right)$, chroma $\left(\mathrm{C}^{*}\right)$, and hue $\left(\mathrm{h}^{\circ}\right)$ of berries collected for anthocyanin analyses were measured, before freezing, with a Minolta colorimeter (CR-200; Minolta, Ramsey, N.J.). Three equidistant measurements were made around the equators of each berry. Lightness values may range from zero (black) to 100 (white) (McGuire, 1992). Chroma indicates the purity or intensity of color, the distance from gray (achromatic) toward a pure chromatic color (McGuire, 1992). Chroma is calculated from the $a^{*}$ and $b^{*}$ values of the CIE Laboratory system scale, starts from zero for a completely neutral color, and does not have an arbitrary end, but intensity increases with magnitude. Hue refers to the color wheel and is measured in angles; green, yellow, and red correspond to 180,90 , and $0{ }^{\circ} \mathrm{C}$, respectively (Carreño et al., 1995; Lancaster et al., 1997; McGuire, 1992).

\section{Results}

\section{3 experiment}

Some treatments that included ABA had slightly greater berry weights compared with other treatments, but the unbalanced treatment structure made it difficult to further evaluate these effects (data not shown). Soluble solids were unaffected by any treatment, but all fruits treated with ABA, ethephon, or both had juices with slightly less titratable acidity than the juices of untreated control fruits (data not shown). Fruits having the least mesocarp puncture resistance were those treated with ABA and ethephon (Table 1). All of the treatments markedly increased skin anthocyanin concentration compared with control fruit (Table 1). The industry standard, $250 \mathrm{mg} \cdot \mathrm{L}^{-1}$ ethephon applied at veraison, increased skin anthocyanin concentrations by $\approx 3.5$ times compared with nontreated fruit. The least effective treatment that included ABA, $1000 \mathrm{mg} \cdot \mathrm{L}^{-1}$ ABA 1 week after veraison plus $250 \mathrm{mg} \cdot \mathrm{L}^{-1}$ ethephon at the same time, was not different from ethephon-treated fruit. Other ABA treatments with or without ethephon increased anthocyanins to levels that were six to eight times that of control fruits and these berries had excessive color.

\section{4 experiment}

In 2004, average soluble solids increased from $20.5{ }^{\circ} \mathrm{C}$ Brix on 14 July to $22.3{ }^{\circ} \mathrm{C}$ Brix on $28 \mathrm{July}$, as expected. However, regardless of the harvest date, neither ABA concentration nor application timing affected berry weight, juice soluble solids, $\mathrm{pH}$, or titratable acidity, and those factors did not interact to affect berry weight or juice composition (data not shown). Mesocarp puncture resistance increased $10 \%$ between harvests, but application 
timing, concentration, or the interaction of the two did not affect puncture resistance at either harvest (Table 2). Skin anthocyanins declined by a factor of 1.5 between the first and second harvest dates. The effect of ABA concentration on skin anthocyanin concentrations depended on the harvest date; on 14 July, no differences were observed, but on 28 July, 150 and $300 \mathrm{mg} \cdot \mathrm{L}^{-1}$ ABA increased anthocyanins by 1.5 times compared with untreated fruit regardless of application time (Table 2). All ABA-treated fruit had a good red color.

\section{5 experiment}

There were no interaction effects among harvest date, PGR application times, or PGR treatments with respect to berry weight, soluble solids, or $\mathrm{pH}$. Berry weight increased from $3.6 \mathrm{~g}$ during the first harvest to $3.9 \mathrm{~g}$ during the second harvest; soluble solids were $18.1,18.9$, and $19.7^{\circ} \mathrm{C}$ Brix at the first, second, and third harvests, respectively. Also, $\mathrm{pH}$ increased with each harvest (data not shown). Titratable acidity decreased between the first and second harvests from 7.00 to $5.44 \mathrm{~g} \cdot \mathrm{L}^{-1}$. The juices of fruits treated with ethephon had slightly less titratable acidities than the juices of fruits receiving any concentration of $\mathrm{ABA}$ or that were nontreated (data not shown).

None of the factors interacted to affect mesocarp puncture resistance. In 2005, puncture resistance was highly variable, decreasing from $501 \mathrm{~g}$ during the first harvest to $481 \mathrm{~g}$ during the second but increasing to $513 \mathrm{~g}$ at the third harvest. Moreover, puncture resistance was slightly less for fruits subjected to the veraison PGR application date compared with the preveraison application date, although the PGR treatments did not affect puncture resistance (data not shown).

Overall, average skin anthocyanin concentrations were unaffected by harvest date, although chroma and hue were lower on the second and third harvest dates compared with the first (data not shown). Harvest date did not interact with the other factors to affect anthocyanin concentrations or the color characteristics of the grapes, but there were highly significant interactions between the application date and PGR treatments with respect to skin anthocyanins and fruit color characteristics (Tables 3, 4, 5, and 6).

The $300 \mathrm{mg} \cdot \mathrm{L}^{-1} \mathrm{ABA}$ and the ethephon treatments increased skin anthocyanin concentrations when applied at any of the application dates tested compared with control treatment, but $150 \mathrm{mg} \cdot \mathrm{L}^{-1} \mathrm{ABA}$ was only effective if applied at or after veraison, and $75 \mathrm{mg} \cdot \mathrm{L}^{-1}$ ABA was only effective when applied postveraison (Table 3 ). When applied preveraison, the skins of ethephon-treated fruits had the most anthocyanins, but when the PGRs were applied at veraison, the 300 $\mathrm{mg} \cdot \mathrm{L}^{-1} \mathrm{ABA}$ treatment was superior to all other treatments, and when applied postveraison, $\mathrm{ABA}$ at any concentration from 75 to $300 \mathrm{mg} \cdot \mathrm{L}^{-1}$ was superior to ethephon treatment, and both had more anthocyanins than nontreated fruits. In general, ABA applications were more effective at increasing an-

Table 1. Effect of ABA and ethephon treatments applied at veraison (ver.) or 1 week after veraison on mesocarp puncture resistance and skin anthocyanin concentration of 'Flame Seedless' berries, 2003.

\begin{tabular}{lcc}
\hline Treatment & $\begin{array}{c}\text { Puncture } \\
\text { resistance }(\mathrm{g})\end{array}$ & $\begin{array}{c}\text { Anthocyanins } \\
\left(\mathrm{mg} \cdot \mathrm{cm}^{-2}\right)\end{array}$ \\
\hline $1000 \mathrm{mg} \cdot \mathrm{L}^{-1}$ ABA ver. & $378.3 \mathrm{c}^{\mathrm{z}}$ & $0.097 \mathrm{~b}$ \\
$1000 \mathrm{mg} \cdot \mathrm{L}^{-1}$ ABA ver. $+250 \mathrm{mg} \cdot \mathrm{L}^{-1}$ ethephon 1 week after & $328.1 \mathrm{~d}$ & $0.097 \mathrm{~b}$ \\
$250 \mathrm{mg} \cdot \mathrm{L}^{-1}$ ethephon ver. & $447.9 \mathrm{~b}$ & $0.054 \mathrm{c}$ \\
$250 \mathrm{mg} \cdot \mathrm{L}^{-1}$ ethephon ver. $+1000 \mathrm{mg} \cdot \mathrm{L}^{-1}$ ABA 1 week after & $293.3 \mathrm{~d}$ & $0.130 \mathrm{a}$ \\
$1000 \mathrm{mg} \cdot \mathrm{L}^{-1}$ ABA $+250 \mathrm{mg} \cdot \mathrm{L}^{-1}$ ethephon ver. & $294.7 \mathrm{~d}$ & $0.128 \mathrm{a}$ \\
$2000 \mathrm{mg} \cdot \mathrm{L}^{-1}$ ABA ver. & $410.4 \mathrm{bc}$ & $0.104 \mathrm{ab}$ \\
$1000 \mathrm{mg} \cdot \mathrm{L}^{-1}$ ABA $+250 \mathrm{mg} \cdot \mathrm{L}^{-1}$ ethephon 1 week after ver. & $324.5 \mathrm{~d}$ & $0.079 \mathrm{bc}$ \\
Nontreated & $512.4 \mathrm{a}$ & $0.016 \mathrm{~d}$ \\
\hline
\end{tabular}

${ }^{z}$ Values are treatments means, $n=15$. Means followed by a different letter within columns are significantly different according to Duncan's multiple range test, $\alpha=0.05$.

Table 2. Effect of timing and concentration of ABA solutions on mesocarp puncture resistance and skin anthocyanin concentration of 'Flame Seedless' berries, 2004.

\begin{tabular}{|c|c|c|c|c|}
\hline \multirow[b]{2}{*}{ Factor } & \multicolumn{2}{|c|}{ July 14} & \multicolumn{2}{|c|}{ July 28} \\
\hline & $\begin{array}{c}\text { Puncture } \\
\text { resistance }(\mathrm{g})\end{array}$ & $\begin{array}{c}\text { Anthocyanins } \\
\left(\mathrm{mg} \cdot \mathrm{cm}^{-2}\right)\end{array}$ & $\begin{array}{c}\text { Puncture } \\
\text { resistance }(\mathrm{g})\end{array}$ & $\begin{array}{c}\text { Anthocyanins } \\
\left(\mathrm{mg} \cdot \mathrm{cm}^{-2}\right)\end{array}$ \\
\hline \multicolumn{5}{|l|}{ Timing } \\
\hline Preveraison & 644.9 & 0.021 & 715.2 & 0.014 \\
\hline Veraison & 629.8 & 0.022 & 717.2 & 0.016 \\
\hline Postveraison & 653.0 & 0.026 & 700.8 & 0.017 \\
\hline \multicolumn{5}{|c|}{ Concentration $\left(\mathrm{mg} \cdot \mathrm{L}^{-1} \mathrm{ABA}\right)$} \\
\hline 0 & 656.0 & 0.017 & 730.4 & $0.012 \mathrm{c}^{\mathrm{z}}$ \\
\hline 75 & 635.3 & 0.025 & 711.5 & $0.014 \mathrm{cb}$ \\
\hline 150 & 627.0 & 0.026 & 706.6 & $0.017 \mathrm{ab}$ \\
\hline 300 & 651.9 & 0.025 & 694.3 & $0.020 \mathrm{a}$ \\
\hline \multicolumn{5}{|l|}{ Significance } \\
\hline Timing & 0.641 & 0.297 & 0.505 & 0.172 \\
\hline Concn & 0.717 & 0.127 & 0.176 & $<0.001$ \\
\hline Timing $*$ concn & 0.891 & 0.536 & 0.930 & 0.237 \\
\hline
\end{tabular}

${ }^{\mathrm{z}}$ Values are treatments means, $\mathrm{n}=20$. Means followed by a different letter within column are significantly different according to Duncan's multiple range test, $\alpha=0.05$. thocyanins the later they were applied, whereas the opposite was true for ethephon (Table 3).

When applied preveraison, both PGRs decreased lightness of the berries, but ethephon was more effective in this regard than any of the ABA concentrations tested (Table 4). However, when applied at veraison, fruits treated with $300 \mathrm{mg} \cdot \mathrm{L}^{-1} \mathrm{ABA}$ were darker than the other fruits, including those treated with ethephon. When applied postveraison, all the ABA-treated fruits were darker than those treated with ethephon, although ethephon-treated fruits were still darker than nontreated fruits. In general, the later that ABA was applied, the darker the fruit, except for the $300 \mathrm{mg} \cdot \mathrm{L}^{-1} \mathrm{ABA}$ treatment, which was most effective at darkening the fruit when applied at veraison. The effect of ethephon on lightness did not change among preveraison, veraison, and postveraison applications.

Chroma values were unaffected by preveraison treatments (Table 5). However, when applied at veraison, all treatments decreased chroma relative to nontreated fruits, and fruits treated with $300 \mathrm{mg} \cdot \mathrm{L}^{-1} \mathrm{ABA}$ had the lowest chroma values of all fruits. When applied postveraison, fruits treated with 150 or $300 \mathrm{mg} \cdot \mathrm{L}^{-1} \mathrm{ABA}$ had lower chroma values than nontreated fruits or fruits treated with ethephon. In general, fruits treated at or after veraison with $\mathrm{ABA}$ had lower chroma values than fruits subjected to those treatments preveraison, whereas the ethephon application time did not change the chroma of the berries.

Fruits treated preveraison with any PGR had lower hue angles than nontreated fruits, and ethephon decreased hue more than ABA did at that time (Table 6). However, for fruits treated at veraison, the $300 \mathrm{mg} \cdot \mathrm{L}^{-1} \mathrm{ABA}$ application reduced hue more than ethephon. All treatments applied postveraison showed a decrease in the hue compared with the control. The effect of $75 \mathrm{mg} \cdot \mathrm{L}^{-1} \mathrm{ABA}$ or ethephon on hue was similar regardless of the application date, whereas 150 or $300 \mathrm{mg} \cdot \mathrm{L}^{-1}$ ABA more effectively decreased hue when applied either at or after veraison.

Lightness had a highly significant inverse curvilinear relationship with anthocyanins (Fig. 1A). As skin anthocyanins increased, lightness decreased such that the fruits appeared darker. The effect of anthocyanin concentration on lightness was particularly striking as anthocyanins increased from near zero through $\approx 0.01 \mathrm{mg} \cdot \mathrm{cm}^{-2}$. As pigment concentrations increased beyond that, they had relatively less effect on lightness. In contrast, there was no clear relationship between chroma and anthocyanin concentration (Fig. 1B). Hue angle, like with lightness, had a highly significant relationship with skin anthocyanin concentrations (Fig. 1C). At low concentrations (up to $0.01 \mathrm{mg} \cdot \mathrm{cm}^{-2}$ ), skin anthocyanins had an even more dramatic effect on hue than they did on lightness, with hue dropping sharply with slight increases in pigments. However, as skin anthocyanins increased above $0.01 \mathrm{mg} \cdot \mathrm{cm}^{-2}$, they had even 
Table 3. Effect of the interaction between application date and ABA and ethephon treatments on the skin anthocyanin concentration of 'Flame Seedless' berries, 2005.

\begin{tabular}{lccccc}
\hline & \multicolumn{4}{c}{ Anthocyanin concn $\left(\mathrm{mg} \cdot \mathrm{cm}^{-2}\right)$} \\
\cline { 2 - 4 } & \multicolumn{4}{c}{ Abscisic acid } & Ethephon \\
\cline { 2 - 5 } & 0 & 75 & 150 & 300 & 250 \\
Application date & $0.007 \mathrm{c}^{\mathrm{z}}$ & $0.009 \mathrm{c}$ & $0.010 \mathrm{c}$ & $0.014 \mathrm{~b}$ & $0.017 \mathrm{a}$ \\
Preveraison & $0.008 \mathrm{c}$ & $0.011 \mathrm{c}$ & $0.018 \mathrm{~b}$ & $0.022 \mathrm{a}$ & $0.015 \mathrm{~b}$ \\
Veraison & $0.009 \mathrm{c}$ & $0.018 \mathrm{a}$ & $0.021 \mathrm{a}$ & $0.021 \mathrm{a}$ & $0.013 \mathrm{~b}$ \\
Postveraison & $0.003^{\mathrm{y}}$ & 0.004 & 0.005 & 0.007 & 0.005 \\
LSD $(0.05)$ & &
\end{tabular}

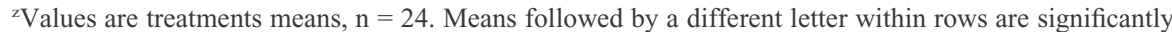
different according to Duncan's multiple range test, $\alpha=0.05$.

${ }^{y}$ Means within columns are significantly different according to LSD when difference is higher than the LSD value.

Table 4. Effect of the interaction between application date and ABA and ethephon treatments on lightness (L*) of 'Flame Seedless' berries, 2005.

\begin{tabular}{lccccc}
\hline & \multicolumn{4}{c}{$\mathrm{L}^{*}$} \\
\cline { 2 - 5 } & \multicolumn{4}{c}{ Conscisic acid $\left(m g \cdot L^{-I}\right)$} & Ethephon \\
\cline { 2 - 5 } & 0 & 75 & 150 & 300 & 250 \\
Application date & $40.42 \mathrm{a}^{\mathrm{z}}$ & $39.16 \mathrm{~b}$ & $38.37 \mathrm{bc}$ & $37.53 \mathrm{c}$ & $36.04 \mathrm{~d}$ \\
Preveraison & $40.06 \mathrm{a}$ & $37.96 \mathrm{~b}$ & $35.96 \mathrm{c}$ & $33.83 \mathrm{~d}$ & $36.07 \mathrm{c}$ \\
Veraison & $39.68 \mathrm{a}$ & $35.96 \mathrm{c}$ & $34.65 \mathrm{~d}$ & $35.43 \mathrm{~cd}$ & $37.21 \mathrm{~b}$ \\
Postveraison & $2.20^{\mathrm{y}}$ & 1.43 & 1.42 & 1.84 & 1.19 \\
LSD $(0.05)$ & &
\end{tabular}

${ }^{\mathrm{z}}$ Values are treatments means, $\mathrm{n}=24$. Means followed by a different letter within rows are significantly different according to Duncan's multiple range test, $\alpha=0.05$.

${ }^{y}$ Means within columns are significantly different according to LSD when difference is higher than the LSD value.

Table 5. Effect of the interaction between application date and ABA and ethephon treatments on chroma (C*) of 'Flame Seedless' berries, 2005.

\begin{tabular}{lccccc}
\hline & \multicolumn{4}{c}{$\mathrm{C}^{*}$} \\
\cline { 2 - 5 } & \multicolumn{4}{c}{ Conscisic acid $\left(m g \cdot L^{-1}\right)$} & Ethephon \\
\cline { 2 - 5 } & 0 & 75 & 150 & 300 & 250 \\
Application date & 12.44 & 11.99 & 12.10 & 12.03 & 12.70 \\
Preveraison & $12.65 \mathrm{a}^{\mathrm{z}}$ & $11.60 \mathrm{~b}$ & $10.83 \mathrm{~b}$ & $9.61 \mathrm{c}$ & $11.67 \mathrm{~b}$ \\
Veraison & $12.42 \mathrm{a}$ & $12.56 \mathrm{a}$ & $11.45 \mathrm{~b}$ & $10.70 \mathrm{~b}$ & $12.44 \mathrm{a}$ \\
Postveraison & $1.10^{\mathrm{y}}$ & 1.03 & 1.17 & 1.18 & 1.10 \\
LSD $(0.05)$ & &
\end{tabular}

${ }^{2}$ Values are treatments means, $\mathrm{n}=24$. Means followed by a different letter within rows are significantly different according to Duncan's multiple range test, $\alpha=0.05$.

${ }^{y}$ Means within columns are significantly different according to LSD when difference is higher than the LSD value.

Table 6. Effect of the interaction between application date and ABA and ethephon treatments on hue angle $\left(h^{\circ}\right)$ of 'Flame Seedless' berries, 2005.

\begin{tabular}{lccccc}
\hline & \multicolumn{4}{c}{$\mathrm{h}^{\circ}$} \\
\cline { 2 - 5 } & \multicolumn{4}{c}{ Abscisic acid } & Ethephon \\
\cline { 2 - 5 } & 0 & 75 & 150 & 300 & 250 \\
\hline Application date & $49.2 \mathrm{a}^{\mathrm{z}}$ & $35.9 \mathrm{~b}$ & $32.8 \mathrm{~b}$ & $32.7 \mathrm{~b}$ & $22.5 \mathrm{c}$ \\
Preveraison & $45.5 \mathrm{a}$ & $38.3 \mathrm{a}$ & $24.1 \mathrm{bc}$ & $16.2 \mathrm{c}$ & $26.2 \mathrm{~b}$ \\
Veraison & $40.8 \mathrm{a}$ & $28.8 \mathrm{~b}$ & $23.4 \mathrm{~b}$ & $26.3 \mathrm{~b}$ & $27.6 \mathrm{~b}$ \\
Postveraison & $16.2^{\mathrm{y}}$ & 10.8 & 8.1 & 11.1 & 7.1 \\
LSD $(0.05)$ & &
\end{tabular}

${ }^{\mathrm{z}}$ Values are treatments means, $\mathrm{n}=24$. Means followed by a different letter within rows are significantly different according to Duncan's multiple range test, $\alpha=0.05$.

${ }^{y}$ Means within columns are significantly different according to LSD when difference is higher than the LSD value.

less effect on hue than they did on lightness as indicated by the relatively shallow slope of the fitted line at the higher concentrations of anthocyanins.

\section{Discussion}

Others found that endogenous concentrations of $\mathrm{ABA}$ were closely related to the increase of soluble solids and the decrease of titratable acidity of grapes that occur during maturation (Coombe, 1976; Düring et al., applications of ABA have negligible effects on grape juice composition.

Berry softening is an undesirable side effect of ethephon treatment (Jensen et al., 1975; Szyjewicz et al., 1984), but the effect that ABA may have on softening is less clear. Lee et al. (1997) reported that ABA did not cause softening of 'Kyoho' grapes, but this cultivar normally has a soft pulp. In our study, the high rates of ABA tested in 2003 generally caused the same or more softening than ethephon, as evidenced by the similar or lesser mesocarp puncture resistance of the ABA-treated fruits compared with that of fruits treated with ethephon or nontreated. Because the 2003 treatments resulted in excessive softening, in subsequent seasons, lower concentrations of ABA (without ethephon) were tested as were different application timings. The lower ABA concentrations tested in 2004 and 2005 did not affect the firmness of 'Flame Seedless' grapes, but neither did ethephon, in 2005. Thus, although ABA only caused softening in one season, we cannot say that ABA treatment causes less softening than ethephon. In 2004, firmness increased from the first to second harvest, and in 2005, fruits were most soft at the middle harvest. The reason for this is uncertain. Many fruits continue to soften as they mature, but in the case of many table grape cultivars, including 'Flame Seedless', it seems that perhaps an increase in berry turgor associated with maturity can increase firmness.

Although treatment with either ethephon or ABA caused few differences in the weight, juice composition, or firmness of the grapes, skin anthocyanin levels and grape color were markedly affected by both compounds. In 2003, the relatively high rates of ABA tested greatly increased skin anthocyanin concentrations, especially when combined with ethephon. However, in 2003, fruits treated with these high rates of ABA, with or without ethephon, developed an excessively darkcolored appearance that was uncharacteristic of the cultivar. Kim et al. (1998) tested the effect of ethephon and ABA on different cultivars and found that anthocyanins either increased or decreased compared with nontreated fruits depending on the cultivar. In their experiment, the use of ethephon or $\mathrm{ABA}$ increased the anthocyanin content of 'Campbell Early', 'Muscat Early', and other hybrid grape cultivars, but the skin anthocyanin content of 'Cabernet Sauvignon' and 'Syrah' at harvest was lower in ethephon and ABAtreated fruit compared with controls. The effect of ABA on anthocyanins seems to be greatest for grapes having fewer pigments (Kim et al., 1998).

The lower concentrations of ABA tested in 2004 and 2005 were still effective at increasing skin anthocyanin concentrations, especially when they were applied at or after veraison. When applied later in the season, ABA in general became more effective but ethephon did not. This was particularly true for the lower concentrations of ABA, 75 and $150 \mathrm{mg} \cdot \mathrm{L}^{-1}$. Depending on the application time, the $150 \mathrm{mg} \cdot \mathrm{L}^{-1} \mathrm{ABA}$ treatment resulted 


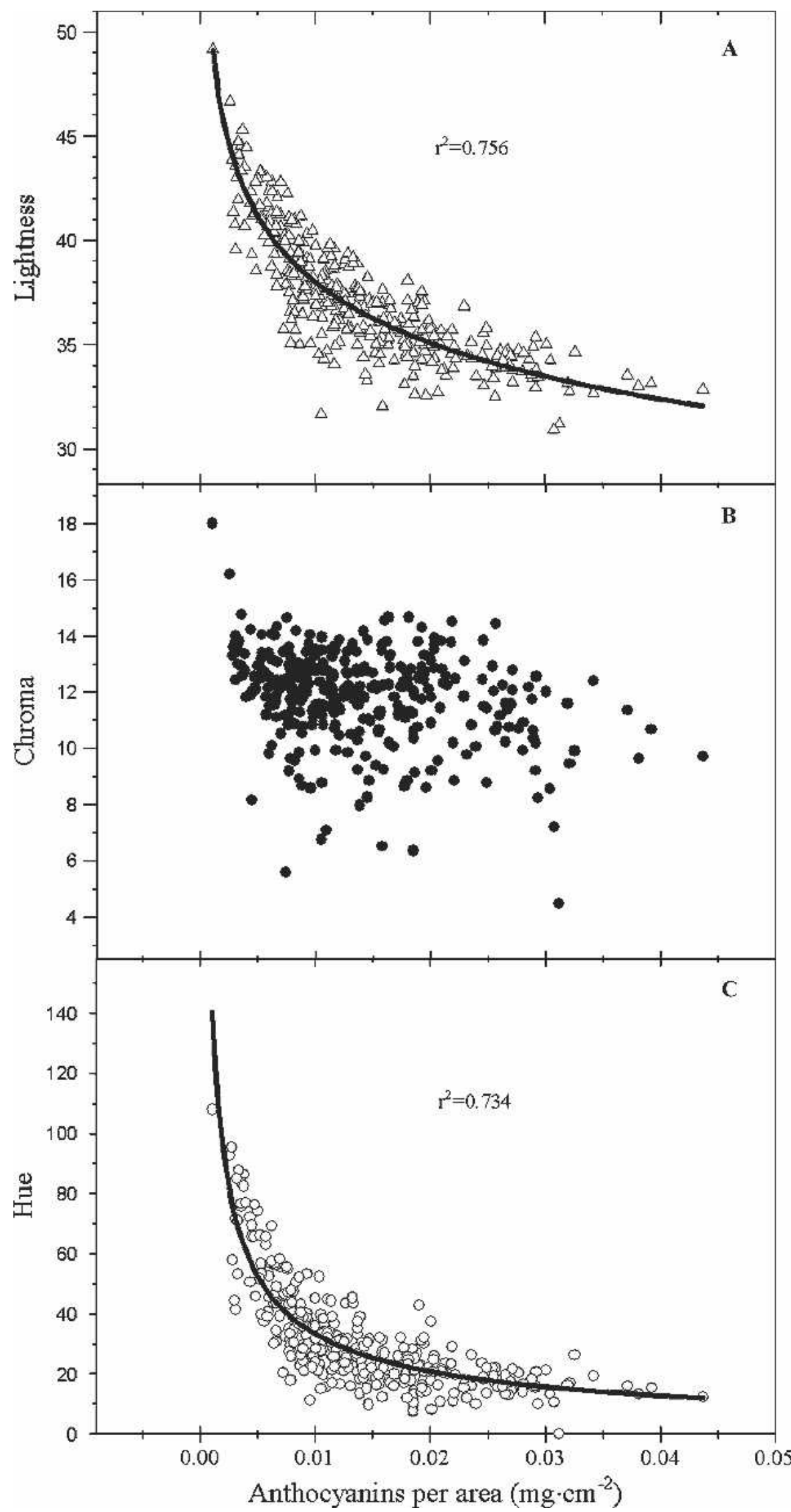

Fig. 1. Relationships between anthocyanin concentration and lightness (A), chroma (B), and hue (C) of 'Flame Seedless' berries. The relationship between anthocyanin concentration and lightness was described by the equation $\left.\mathrm{y}=22.3375 \cdot \mathrm{x}^{-0.115338}\right), r^{2}=0.76$ (Figure 1A). The relationship between anthocyanin concentration and hue was described by the equation $\mathrm{y}=-1.95667 \cdot\left(1-\mathrm{x}^{-0.627948}\right)$, $r^{2}=0.73$ (Fig. 1C). in less, the same, or higher skin anthocyanin concentrations than ethephon-treated fruit, whereas $300 \mathrm{mg} \cdot \mathrm{L}^{-1}$ of $\mathrm{ABA}$ applied at or after veraison resulted in more anthocyanins than ethephon treatment. In 2004, application time did not affect firmness or anthocyanin concentration. The highest anthocyanin levels were achieved with the $150 \mathrm{mg} \cdot \mathrm{L}^{-1}$ of ABA treatment, which did not affect firmness. The next season the highest anthocyanin concentration was observed with $300 \mathrm{mg} \cdot \mathrm{L}^{-1}$ of $\mathrm{ABA}$ at or after veraison, whereas $150 \mathrm{mg} \cdot \mathrm{L}^{-1}$ applied at the same timings was as good or better than any ethephon treatment.

Certain application times and concentrations of ABA were also superior to ethephon with respect to color characteristics of the berries. In general, fruits treated with $\mathrm{ABA}$ at or after veraison were darker than fruits treated with ethephon or nontreated fruits. Only fruits treated with $300 \mathrm{mg} \cdot \mathrm{L}^{-1} \mathrm{ABA}$ at veraison had lower hue angles (were more red-colored) than ethephon-treated fruits, but when lightness and hue angle are considered together, ABA treatments at or after veraison resulted in fruits that appeared to have a darker red coloration than ethephon-treated fruits. The best results, however, were observed in fruits treated at veraison with 150 or $300 \mathrm{mg} \cdot \mathrm{L}^{-1}$ of $\mathrm{ABA}$, which had better color than fruits treated with ethephon at any time.

The darker and more red-colored fruit obtained from the $300 \mathrm{mg} \cdot \mathrm{L}^{-1} \mathrm{ABA}$ at veraison treatment also had lower chroma values than fruits treated at the same time with ethephon. Because higher chroma values are considered to indicate more pure or intense color, lower chroma values may seem undesirable. As berries mature, their color changes from a relatively pure green to yellow and, eventually, to red. The lower chroma values of treated fruits might reflect changes associated with the transition from yellow to red. These gradual changes are not uniform across the surface of the berry so treatments that enhance color break might be expected to temporarily decrease chroma. As more cells and berries accumulate anthocyanins, the berries develop a more uniform red color and consequently the chroma values may increase again. A decline in lightness and chroma associated with the coloration of berries was observed by others (Carreño et al., 1995). Kim et al. (1998) analyzed the effect of ABA on grape color using the CIE 1976 (L*, a*, b*) system (McGuire, 1992) and found that $\mathrm{L}^{*}$ and $\mathrm{b}^{*}$ decreased and $\mathrm{a}^{*}$ increased in proportion to coloration. The conversion of these $\mathrm{L}^{*}, \mathrm{a}^{*}$, and $\mathrm{b}^{*}$ to lightness, chroma, and hue (McGuire, 1992) translates into lower lightness and hue values and in general increased chroma, but the relative changes in $a^{*}$ and $b^{*}$ can affect chroma.

Skin anthocyanin concentrations had a pronounced effect on lightness and hue of the berries, especially at low pigment concentrations. As anthocyanins increased beyond $\approx 0.01 \mathrm{mg} \cdot \mathrm{cm}^{-2}$, they had less effect on color characteristics so it may be difficult to predict skin anthocyanin concentrations from 
the color characteristics of dark-colored fruits as suggested by others (Lancaster et al., 1997). Even so, our data suggest that researchers hoping to demonstrate the effect of certain cultural practices on berry color should consider measuring color directly and not rely solely on skin anthocyanin concentrations, especially if the control fruits are relatively well-colored. Others have proposed a color index to classify red grape berries (Carreño et al., 1995, 1997; Fernández-López et al., 1998), but the index condenses tristimulus measurements of color into a single variable, thus reducing the descriptive power of a tristimulus measurement (McGuire, 1992).

In conclusion, our results suggest that $\mathrm{ABA}$ is more effective than ethephon at improving the color of 'Flame Seedless' grapes and therefore its use may increase production efficiency. Moreover, we demonstrated that although the best time for ABA application is at veraison, its use later in the season still improved color, whereas ethephon effectiveness was reduced with time after veraison. Abscisic acid treatments did cause berry softening, but many effective ABA treatments did not cause more softening than the industry standard ethephon. Applications of ABA between 150 and $300 \mathrm{mg} \cdot \mathrm{L}^{-1}$ at veraison for warmer areas or seasons represent a good compromise between good uniform color and firmness for 'Flame Seedless' berries. Finally, the analysis of anthocyanins and color provides new details regarding the relationships between pigments and color. The increase in anthocyanin concentration is not linearly correlated with color, and 'Flame Seedless' anthocyanin concentrations between 0.01 and $0.04 \mathrm{mg} \cdot \mathrm{cm}^{-2}$ have very little effect on lightness or hue. Thus, anthocyanin measurements alone may be inadequate to evaluate the color of red table grapes.

\section{Literature Cited}

Carreño, J., A. Martínez, L. Almela, and J.A. Fernández-López. 1995. Proposal of an index for the objective evaluation of the colour of red table grapes. Food Res. Int. 28:373-377.

Carreño, J., L. Almela, A. Martínez, and A. Fernández-López. 1997. Chemotaxonomical classification of red table grapes based on anthocyanin profile and external colour. Lebensm-Wiss Technol. 30:259-265.

CASS. 2004. California Grape Acreage. California Agr. Stat. Serv., Sacramento, Calif. 20 Feb. 2006. http://www.nass.usda.gov/ca/bul/acreage/indexgab.htm.

Coombe, B.G. 1976. Abscisic acid and sugar accumulation in the grape berry. The 9th International Conference on Plant Growth Substances. Lausanne, Switzerland, p. 62-64.

Coombe, B.G. and C.R. Hale. 1973. The hormone content of ripening grape berries and the effects of growth substances treatments. Plant Physiol. 51:629-634.

Dokoozlian, N.K. and D. Hirschfelt. 1995. The influence of cluster thinning at various stages of fruit development on Flame Seedless table grapes. Amer. J. Enol. Vitic. 46:429-436.

Düring, H., G. Alleweldt, and R. Koch. 1978. Studies on hormonal control of ripening in berries of grape vines. Acta Hort. 80:397-405.

Fernández-López, J.A., L. Almela, J.A. Muñoz, V. Hidalgo, and J. Carreño. 1998. Dependence between colour and individual anthocyanin content in ripening grapes. Food Res. Int. 31: 667-672.

Gomez, K.A. and A.A. Gomez. 1984. Statistical Procedures for Agricultural Research. 2nd ed. Wiley, N.Y.

Han, D.H., S.M. Lee, C.H. Lee, and S.B. Kim 1996. Effects of ABA and ethephon treatments on coloration and fruit quality in Kyoho grape. J. Kor. Soc. Hort. Sci. 37:416-420.

Jensen, F.L., J. Kissler, W. Peacock, and G. Leavitt. 1975. Effect of ethephon on color and fruit characteristics of Tokay and Emperor table grapes. Amer. J. Enol. Vitic. 26:79-81.

Jensen, F.L., J. Kissler, W. Peacock, G. Leavitt, H. Andris, and D. Luvisi. 1982. Color and maturity promotion in table grapes with ethephon, p. 118-121. In: Grape and Wine Centennial Symp. Proc. Univ. of California Press, Davis.

Kataoka, I., A. Sugiura, N. Utsunomiya, and T. Tomana. 1982. Effect of abscisic acid and defoliation on anthocyanin accumulation in Kyoho grapes (Vitis vinifera L. x $V$. labruscana Bailey). Vitis 21:325-332.

Kim, S.K., J.T. Kim, S.H. Jeon, Y.S. Nam, and S.H. Kim. 1998. Effects of ethephon and ABA application on coloration, content and composition of anthocyanin in grapes (Vitis spp.). J. Kor. Soc. Hort. Sci. 39:547-554.

Kliewer, W.M. 1970. Effect of day temperature and light intensity on coloration of Vitis vinifera $\mathrm{L}$. grapes. Amer. Soc. Hort. Sci. 95:693-697.

Lancaster, J.E., C. Lister, P.F. Reay, and C.M. Triggs. 1997. Influence of pigment composition on skin color in a wide range of fruits and vegetables. J. Amer. Soc. Hort. Sci. 122:594-598.
Lee, J.C. and T. Tomana. 1980. Physiological study on anthocyanin development in grapes. II. Effect of sucrose, abscisic acid and indoleacetic acid on the anthocyanin development in Kyoho grape (Vitis labruscana). J. Kor. Soc. Hort. Sci. 21:158-163.

Lee, J.C., T. Tomana, N. Utsunomiya, and I. Kataoka. 1979. Physiological studies on the anthocyanin development in grape. I. Effect of fruit temperature on the anthocyanin development in Kyoho grape. J. Kor. Soc. Hort. Sci. 20:55-65.

Lee, K.S., J.C. Lee, Y.S. Hwang, and I.B. Hur. 1997. Effects of natural type (S)-(+)-abscisic acid on anthocyanin accumulation and maturity in 'Kyoho' grapes. J. Kor. Soc. Hort. Sci. 38:717-721.

Matsushima, J., S. Hiratsuka, N. Taniguchi, R. Wada, and N. Suzaki. 1989. Anthocyanin accumulation and sugar content in the skin of grape cultivar 'Olympia' treated with ABA. J. Jpn. Soc. Hort. Sci. 58:551-555.

Mazza, G. 1995. Anthocyanins in grapes and grape products. Crit. Rev. Food Sci. Nutr. 35: 341-371.

McGuire, R.G. 1992. Reporting of objective color measurements. HortScience 27:1254-1255.

Peppi, M.C. 2004. Color development studies in table grapes. Univ. Calif., Davis, MS Thesis.

Ribéreau-Gayon, P. 1982. The anthocyanins of grapes and wines, p. 209-244. In: P. Markakis (ed.). Anthocyanins as food colors Academic, New York.

Spayd, S.E., J.M. Tarara, D.L. Mee, and J.C. Ferguson. 2002. Separation of sunlight and temperature effects on the composition of Vitis vinifera cv. Merlot berries. Amer. J. Enol. Viticult. 53:171-182.

Szyjewicz, E., N. Rosner, and W.M. Kliewer. 1984. Ethephon (2-Chloroethyl) phosphonic acid, Ethrel, CEPA) in viticulture, a review. Amer. J. Enol. Viticult. 35:117-123.

Taiz, L. and E. Zeiger. 2002. Plant physiology. 3rd ed. Sinauer Publishers, Sunderland, Mass.

Tomana, T., N. Utsunomiya, and I. Kataoka. 1979. The effect of environmental temperatures on fruit ripening on the tree. II. The effect of temperatures around whole vines and clusters on coloration of Kyoho grapes. J. Jpn. Soc. Hort. Sci. 48:261-266.

Walton, D. 1980. Biochemistry and physiology of abscisic acid. Ann. Rev. Plant Physiol. 31: 453-489.

Winkler, A.J., J.A. Cook, W.M. Kliewer, and L.A. Lider. 1974. General viticulture. 2nd ed. Univ. of Calif. Press, Berkeley, Calif.

Zeevaart, J.A.D. and R.A. Creelman. 1988. Metabolism and physiology of abscisic acid. Ann. Rev. Plant Physiol. Plant Mol. Biol. 39:439-473. 